\title{
The fundaments of CBCT and its use for evaluation of paranasal sinuses: review of literature
}

Liana Matos Ferreira, DDS, MSa, Yuri Nejaim, DDS, MS, $\mathrm{PhD}^{\mathrm{a}}$, Deborah Queiroz Freitas, DDS, MS, $\mathrm{PhD}^{\mathrm{a}}$, Cínthia Pereira Machado Tabchoury, DDS, MS, $\mathrm{PhD}^{\mathrm{b}}$

a Department of Oral Diagnosis, Division of Oral Radiology. Piracicaba Dental School, University of Campinas. Piracicaba, São Paulo, Brazil.

${ }^{b}$ Department of Physiological Science. Piracicaba Dental School, University of Campinas. Piracicaba, São Paulo, Brazil.
Image methods such as Magnetic Resonance Imaging (MRI), Computed Tomography (CT) and Cone Beam Computed Tomography (CBCT) are powerful tools to help clinicians on diagnosis and preoperative planning. They provide an accurate view of regional anatomy, anatomical variations and the presence of diseases. Compared to CT, CBCT produces images with adequate spatial resolution with smaller fields of view at lower radiation doses. It has emerged as a potential alternative for obtaining 3D evaluation of the paranasal sinus at relatively modest costs. The aim of this review was to verify whether $\mathrm{CBCT}$ images offer an additional value to the evaluation of paranasal sinus.

Keywords: Paranasal Sinuses. Diagnostic Imaging. Cone Beam Computed Tomography.

\author{
*Corresponding author: \\ Liana Matos Ferreira. \\ University of Campinas, Piracicaba \\ Dental School, Department \\ of Oral Diagnosis. \\ Av. Limeira, 901 \\ Zip Code 13414-903 \\ Piracicaba, Sao Paulo, Brazil. \\ Phone: +55 - 19 -2106-5327 \\ E-mail: liana.rj@gmail.com \\ Received: October 17, 2017 \\ Accepted: March 17, 2018
}




\section{Introduction}

The purpose of radiological evaluation of the paranasal sinuses and related structures is to provide an accurate description of the regional anatomy, any osseous changes or variations, sinus mucosa, fluid levels and to establish the presence and extent of diseases ${ }^{1,2}$. Available imaging techniques that might be used in this situation include two-dimensional X-rays, like Waters' and panoramic, Computed Tomography (CT), Magnetic Resonance Imaging (MRI), and more recently Cone beam computed tomography $(\mathrm{CBCT})^{1,3}$ - these are summarized in table 1 . Plain films are widely available; however, provide insufficient detail to allow surgical planning. At best, they give only an overview of the anatomy and underlying pathology, as they are limited to displaying three-dimensional structures in a two-dimensional plane. The technological advances in radiological imaging from $2 \mathrm{D}$ projection radiography towards $3 \mathrm{D}$ and interactive imaging applications have made an enormous impact in head imaging and have increased surgeon's ability to depict accurately the status of structures within the paranasal sinus region and to delineate the location and extent of pathology ${ }^{4,5}$. Multidetector CT (MDCT) and MRI have the advantage of being able to show fine anatomic detail in serial tomographic sections ${ }^{1,6}$. MRI allows excellent visualization of soft tissues, but does not adequately represent the bone walls and paranasal sinuses ostia; on the other hand, MDCT provides a lot of information, both about the bony part as soft tissue, remaining as technique of choice for assessing the presence and extent of disease in the paranasal sinuses. Additionally, the coronal sections perpendicular to the hard palate allow optimal viewing ostiomeatal complex?

Introduced in 1998, CBCT is increasingly used for 3-dimensional imaging in maxillofacial radiology, generates high-resolution isotropic volume data and could, therefore, show benefits for evaluating the bony aspects of the maxillary sinus by using a lower dose of radiation². Although CT is considered as the "gold standard" in imaging for visualization of the paranasal sinus, CBCT is gaining increasing popularity in this respect ${ }^{4}$. Even though, a large dose of ionizing radiation is generally delivered by medical computed tomography; in this way, CBCT technology has achieved considerable reduction of absorbed radiation doses, with equal image qualities and less artifacts for visualizing the maxillofacial bone structures compared to MDCT imaging?

Paranasal sinus 3D images are relevant for the planning of procedures, since it allows the direct visualization of anatomical variations and pathological conditions, which when combined with the clinical examination, can provide to the patient treatment options or referral to specialists, in cases that are not directly linked to dentistry. Therefore, this review of literature aims to present the fundaments of CBCT as well its application on evaluation of paranasal sinuses.

\section{Paranasal Sinus Image Techniques - Comparative Aspects}

For many years, conventional X-rays, like panoramic and Water's radiography, have been used to investigate the paranasal sinuses ${ }^{3}$. However, 2D radiographic images are difficult to interpret because of the overlapping of ostiomeatal complex and osseous structure ${ }^{8,9}$. Generally, they are efficient to display the regional morphology, character- 
Table 1. Summary of literature review of diagnostic imaging modalities in paranasal sinuses.

\begin{tabular}{|c|c|c|c|c|}
\hline Author & $n$ & Objectives & $\begin{array}{l}\text { Imaging } \\
\text { modality }\end{array}$ & Findings \\
\hline $\begin{array}{l}\text { Konen et al. } \\
2000\end{array}$ & 134 & $\begin{array}{l}\text { Diagnosis of } \\
\text { paranasal sinusitis }\end{array}$ & $\begin{array}{l}\text { MDCT and } \\
\text { Water's }\end{array}$ & $\begin{array}{c}\text { The diagnosis by Water's view was very poor. MDCT } \\
\text { with a low dose resolution is recommended. }\end{array}$ \\
\hline $\begin{array}{l}\text { Rafferty et al. } \\
2005\end{array}$ & 12 & $\begin{array}{l}\text { Assist surgical } \\
\text { approach to the } \\
\text { frontal recess }\end{array}$ & $\begin{array}{l}\text { Endoscopy } \\
\text { and CBCT }\end{array}$ & $\begin{array}{l}\text { СBCT increased surgical confidence in accessing the } \\
\text { frontal recess, resolved ambiguities with anatomical } \\
\text { variations and provided valuable teaching information } \\
\text { to surgeons in training in preoperative planning }\end{array}$ \\
\hline $\begin{array}{l}\text { Daly et al. } \\
2006\end{array}$ & & $\begin{array}{l}\text { Performance } \\
\text { as a function of } \\
\text { dose and other } \\
\text { acquisition/ } \\
\text { reconstruction } \\
\text { parameters }\end{array}$ & СBCT & $\begin{array}{l}\text { СВCT was sufficient for guidance of head and neck } \\
\text { procedures. The dose was comparable to or less } \\
\text { than the effective dose of a typical diagnostic MDCT. }\end{array}$ \\
\hline $\begin{array}{l}\text { Bremke et al. } \\
2009\end{array}$ & 23 & $\begin{array}{l}\text { To analyze the } \\
\text { anterior skull base }\end{array}$ & СBCT & $\begin{array}{l}\text { The surgical key landmarks were possible in all } \\
\text { patients. }\end{array}$ \\
\hline $\begin{array}{l}\text { Ritter et al. } \\
2011\end{array}$ & 129 & $\begin{array}{l}\text { To assess the } \\
\text { prevalence of } \\
\text { pathologic findings } \\
\text { in the maxillary } \\
\text { sinus }\end{array}$ & СBCT & $\begin{array}{l}\text { Pathologies in the maxillary sinus are frequently } \\
\text { found in CBCT imaging. CBCT is applicable for } \\
\text { diagnosis and treatment planning. }\end{array}$ \\
\hline $\begin{array}{l}\text { Minni et al. } \\
2012\end{array}$ & 500 & $\begin{array}{l}\text { Study of frontal } \\
\text { recess and } \\
\text { especially its } \\
\text { anatomical } \\
\text { variants in a youth } \\
\text { population }\end{array}$ & СВCT & $\begin{array}{l}\text { CBCT may be used in the analysis of frontal recess } \\
\text { pathologies. }\end{array}$ \\
\hline $\begin{array}{l}\text { Göçmez et al. } \\
2013\end{array}$ & 50 & $\begin{array}{l}\text { To evaluate the } \\
\text { anatomy of the } \\
\text { sphenoid ostium }\end{array}$ & MDCT & $\begin{array}{l}\text { With MDCT, surgeons can make a pre-operative 3D } \\
\text { evaluation of the sphenoid ostium. }\end{array}$ \\
\hline Bui et al. 2014 & 10 & $\begin{array}{l}\text { To create a 3D } \\
\text { model of the } \\
\text { nasal cavity and } \\
\text { paranasal sinuses }\end{array}$ & СBCT & $\begin{array}{l}\text { Automated CBCT segmentation of the airway and } \\
\text { paranasal sinuses was highly accurate. }\end{array}$ \\
\hline $\begin{array}{l}\text { Demeslay } \\
\text { et al. } 2015\end{array}$ & 15 & $\begin{array}{l}\text { To assess the } \\
\text { morphological } \\
\text { concordance } \\
\text { between CBCT and } \\
\text { CT in the sinonasal } \\
\text { anatomy }\end{array}$ & $\begin{array}{l}\text { CBCT and } \\
\text { MDCT }\end{array}$ & $\begin{array}{c}\text { CBCT represents a valid, reproducible and safe } \\
\text { technique }\end{array}$ \\
\hline $\begin{array}{l}\text { Zojaji et al. } \\
2015\end{array}$ & 64 & $\begin{array}{l}\text { To evaluate the } \\
\text { agreement of } \\
\text { image modalities } \\
\text { in patients } \\
\text { with chronic } \\
\text { rhinosinusitis }\end{array}$ & $\begin{array}{l}\text { Endoscopy } \\
\text { and CBCT }\end{array}$ & $\begin{array}{l}\text { CBCT has nearly the same diagnostic accuracy as } \\
\text { sinus endoscopy. }\end{array}$ \\
\hline $\begin{array}{l}\text { Al Abduwani } \\
\text { et al. } 2016\end{array}$ & 121 & $\begin{array}{l}\text { To compare the } \\
\text { absorbed dose and } \\
\text { image quality }\end{array}$ & $\begin{array}{l}\text { CBCT and } \\
\text { MDCT }\end{array}$ & $\begin{array}{c}\text { The dose of CBCTs was approximately } 40 \% \text { lower when } \\
\text { compared to standard MDCT examinations and } 30 \% \\
\text { lower when compared to low dose sinus MDCT scans. } \\
\text { The visualization of high-contrast bone morphology on } \\
\text { CBCT was comparable to standard sinus MDCT. Soft } \\
\text { tissue visibility was limited. }\end{array}$ \\
\hline $\begin{array}{l}\text { Rani et al. } \\
2017\end{array}$ & 60 & $\begin{array}{l}\text { To estimate age } \\
\text { and sex using the } \\
\text { dimensions and } \\
\text { volume of the } \\
\text { maxillary sinus }\end{array}$ & MRI & $\begin{array}{l}\text { MRI measurements of maxillary sinuses may be } \\
\text { useful to support gender and age estimation in } \\
\text { forensic radiology. }\end{array}$ \\
\hline
\end{tabular}

MDCT, multidetector computed tomography; $\mathrm{CBCT}$, cone beam computed tomography; MRI, magnetic resonance imaging 
ize the extent and localization of disease and describe anatomical variants of paranasal sinuses ${ }^{10}$; however, radiographic images allows limited value in the diagnosis of maxillary sinusitis and is less sensitive for detecting abnormalities in other sinuses ${ }^{3}$.

MRI is ideal for assessing soft-tissue masses, mucosa and extension of infectious/malignant disease processes beyond the paranasal sinuses. Imaging of the paranasal sinuses must include high-resolution ( $3 \mathrm{~mm}$ ) T1- weighted and T2-weighted images, not only of the sinonasal cavity but also of the orbit, skull base, and the adjacent intracranial compartment ${ }^{1}$, which is provided by MRI. The use of non-ionising radiation is an advantage of this technique ${ }^{1,10}$. While offering excellent soft tissue definition, MRI provides poor bony definition, which is so critical in the frontal sinus and anterior skull base ${ }^{11}$.

MDCT is a valuable too ${ }^{10}$. for confirmation the clinical diagnosis of the paranasal sinuses, provides detailed images of the sinuses and gives the examiner a clear view of the areas that are key in the pathogenesis of rhinosinusitis. MDCT also reveals the anatomical details of the nose and paranasal sinuses in relation to vital adjacent structures ${ }^{3}$ and allows 3D observation and clear visualization of the inflammatory changes and pathologic status in the nasal and paranasal sinus mucosa ${ }^{12}$. The treatment of choice of chronically infected sinuses is the surgical clearance that maintains the ventilation and drainage. To achieve this goal, there should be some diagnostic modalities, which guide towards exact diagnosis and safe intervention. Over the past few decades, both MDCT and nasal endoscopy have been used successfully as diagnostic modalities in sinus disease ${ }^{5,13}$. Moreover, MDCT imaging of sinonasal region has become the gold standard in the evaluation of patients with chronic sinusitis. Its ability to accurately map out the bony and soft tissue anatomy of the paranasal sinuses has proven invaluable to the endoscopic surgeon ability to depict accurately the status of structures within the paranasal sinus region and to delineate the location and extent of pathology 5 .

Despite the fact that MDCT scan of the paranasal sinuses can be recommended in case of normality and abnormality of the paranasal sinuses or in patients with chronic sinusitis, the high radiation dose and costs do not allow its usage routinely8,12,14. After all, the MDCT cannot stand alone as a gold standard for the diagnosis of rhinosinusitis because it may be positive in the absence of clinical disease. History and physical examination should be taken into consideration when evaluating the MDCT scan. If MDCT findings are not interpreted in light of signs and symptoms, a person with incidental abnormal findings may be labeled as having a sinus condition. In such cases, the diagnosis is incorrect, and inappropriate treatment is often initiated ${ }^{3}$.

Nevertheless, in the last two decades, CBCT has been emerging, and now, it is widely used in dentistry, due to its high image resolution, low radiation dose and low costs, compared to MDCT. Moreover, the boundaries between empty spaces and soft tissues or bones are well defined ${ }^{12,13}$. Because of these advantages, CBCT currently has become a valuable method for the evaluation paranasal sinus. Further prospective studies are required to confirm that.

\section{CBCT}

CBCT is a 3-dimensional (3D) X-ray-based volume acquisition imaging modality, first introduced in $1998^{14}$. Offering the advantage of lower radiation dose ${ }^{4,10,14-16}$, CBCT 
has been widely used in dental practice for various purposes such as maxillary sinus evaluation, oral surgery, evaluation of temporomandibular joint, orthodontic evaluation, implant planning, and craniofacial trauma evaluation and treatment ${ }^{2,8,14}$. After these primary applications, CBCT has gained popularity and is now increasingly being used for the diagnostic imaging of the head and neck region and the ear, nose, and throat area, mucosal thickness, nasal septum deviation, conchal hypertrophy, bullous concha, and retention cysts in these areas ${ }^{2,14,16}$. In CBCT systems, the X-ray beam forms a conical geometry between the source and the detectors; in addition, digital flat-panel detectors replace the row(s) of detectors in MDCT. As result, a major difference is the isotropic nature of acquisition and reconstruction that is used in CBCT systems (i.e., cubic voxels). The fact that each voxel is isotropic explains the high fidelity of the reconstructions in any plane used in CBCT imaging ${ }^{4,16}$. The main advantages of CBCT over MDCT scanning are lower radiation dose (around 10 times lower), lower costs, shorter scanning time, providing very thin slices in any plane, automatic generation of surface and volume reconstructions, easy access, and higher spatial resolution, 4,8,10,12,14,16-18.

\section{Technical aspects of CBCT}

The cone beam technique involves a single scan of $360^{\circ}$ for the majority of machines, in which the X-ray source and a reciprocating area detector synchronously move around the patient's head, which is stabilized with a head holder ${ }^{19}$. During the rotation, multiple (from 150 to more than 1000) sequential planar projection images of the field of view (FOV) are acquired. The dimensions of the FOV or scan volume able to be covered depend primarily on the detector size and shape, the beam projection geometry, and the ability to collimate the beam. The shape of the scan volume can be either cylindric or spherical (eg, NewTom 3G). Collimation of the primary X-ray beam limits $\mathrm{x}$-radiation exposure to the region of interest selected by the professional. Field size limitation, therefore, ensures that an optimal FOV can be selected for each patient, based on disease presentation and the region designated to be imaged. CBCT systems can be categorized according to the available FOV or selected scan volume height as follows: Localized region: approximately $5 \mathrm{~cm}$ or less (eg, dentoalveolar, temporomandibular joint); Single arch: 5 to $7 \mathrm{~cm}$ (eg, maxilla or mandible); Interarch: 7 to $10 \mathrm{~cm}$ (eg, mandible and superiorly to include the inferior concha); Maxillofacial: 10 to $15 \mathrm{~cm}$ (eg, mandible and extending to Nasion); Craniofacial: greater than $15 \mathrm{~cm}$ (eg, from the lower border of the mandible to the vertex of the head) ${ }^{19}$. In general, small FOV and high-resolution scans are optimal for detailed diagnostic tasks (e.g. endodontics), while large volume scans will be able to deliver better 3D models and a comprehensive radiologic view of the maxillofacial skeleton and partly of the soft tissue therein 2,8 .

\section{Effective dose of СВСТ}

The effective dose takes into account the radiation dose produced by the imaging system and the radiation sensitivity of the tissues that the $\mathrm{X}$-ray beam is passing through during the exposure sequence. Effective dose is measured in Sieverts (Sv) and is often expressed in microsieverts $(\mathrm{Sv})^{20}$. The radiation dose produced by a CBCT system is dependent on a number of factors: the nature of the X-ray beam i.e. whether 
it is continuous or pulsatile, the degree of rotation of the $\mathrm{X}$-ray source and detector and the size of the FOV. Moreover, the amount and type of beam filtration and the $\mathrm{kV}, \mathrm{mA}$ and voxel size settings may also influence ${ }^{21}$. Although MDCT is the gold standard for radiologic examination of the paranasal sinuse ${ }^{10}, \mathrm{CBCT}$ in dental and sinus applications is generally considered as a low-dose alternative to MDCT scanners ${ }^{24}$. This dose reduction is significant because radiosensitive organs are present in the field explored during sinus imaging, particularly of pediatric patients ${ }^{16}$

\section{Advantages of CBCT}

As exposed previously, CBCT technology has emerged as a potential alternative for obtaining $3 \mathrm{D}$ evaluation of the paranasal sinus at relatively modest costs, with easy access and a short scanning time compared with MDCT and MRI $1,8,10,14,22,23$. CBCT exposes the patient to substantially lower radiation compared with standard MDCT ${ }^{24}$ and, although MRI is still superior in soft tissue rendering, its use is limited by its cost and restricted accessibility ${ }^{15}$. CBCT has become a diagnostic method to analyze airways characteristics, craniofacial growth, dentomaxillofacial pathology and obstructive sleep apnea ${ }^{15}$, considering its capacity to define the boundaries between soft tissue and empty spaces (air) accurately.

The advantage of reduced CBCT exposure over MDCT can be explained due to the conical geometry of the $\mathrm{X}$-ray beam and to the pulsed rather than continuous emission in majority of the machines ${ }^{22}$, which means that actual exposure time is markedly less than scanning time. This technique considerably reduces patient radiation dose ${ }^{19}$. With correct patient positioning, a selected volume of $10 \times 10 \mathrm{~cm}$ is sufficient to display the nasal cavity, lateral nasal wall, paranasal sinuses and adjacent vital structures ${ }^{25}$. CBCT generally acquires all basis projection images in a single rotation, so scan time can be minimized. An entire head sometimes can be scanned in $10 \mathrm{~s}$ or less ${ }^{4}$, with realistic representation. Added to this, CBCT imaging of the sinuses provides excellent contrast between air and mucosa ${ }^{16}$. These advantages make the system attractive for scanning paranasal sinus.

\section{Limitations of CBCT}

The main drawback of $\mathrm{CBCT}$ is its dynamic range, which is insufficient for displaying contrast within soft tissue and the presence of metal artefact ${ }^{10,12,26}$. The contrast resolution is limited by scattered radiation and the divergence of the X-ray beam over the area detector that produces a large variation in, or no uniformity of, the incident X-ray beam on the patient. These factors contribute to increased image noise. With regard to metal, an artifact is any distortion or error in the image, unrelated to the subject being studied, that can impair the diagnostic ${ }^{19}$. It happens when the CBCT X-ray beam encounters an object of very high density (eg, metallic restorations, dental implants), with absorption of lower energy photons in the beam by the structure rather than higher energy photons; then, the mean energy of the X-ray beam increases. This is called 'beam hardening' and the phenomenon produces two types of artifact: distortion of metallic structures and the emergence of streaks and dark bands between two dense structures ${ }^{21,27}$. 


\section{Applications of $\mathrm{CBCT}$ in paranasal sinus}

\section{Intraoperative guidance}

CBCT generates images in the coronal, axial, sagittal, parasagittal (Figure 1) and any other planes that the professional needs. These three dimensional information can be used to assist the surgeon in the preoperative planning endoscopic sinus surgery and allow the surgeon to correlate positional information regarding the patient's anatomy as it is observed intraoperatively with a radiological image obtained preoperatively, reducing the risk of serious complication ${ }^{11,25,28}$. Endoscopy of the paranasal sinuses allows the observation of anatomical areas and the evaluation of sinonasal lesions and their relationship with endonasal structures. However, endoscopy is an invasive and costly method, needs local or general anesthesia, cannot be applied to all patients and may be associated with severe complications. Regarding these limitations, finding an alternative diagnostic modality is beneficial. CBCT may be an alternative modality for diagnostic sinus endoscopy ${ }^{14}$.
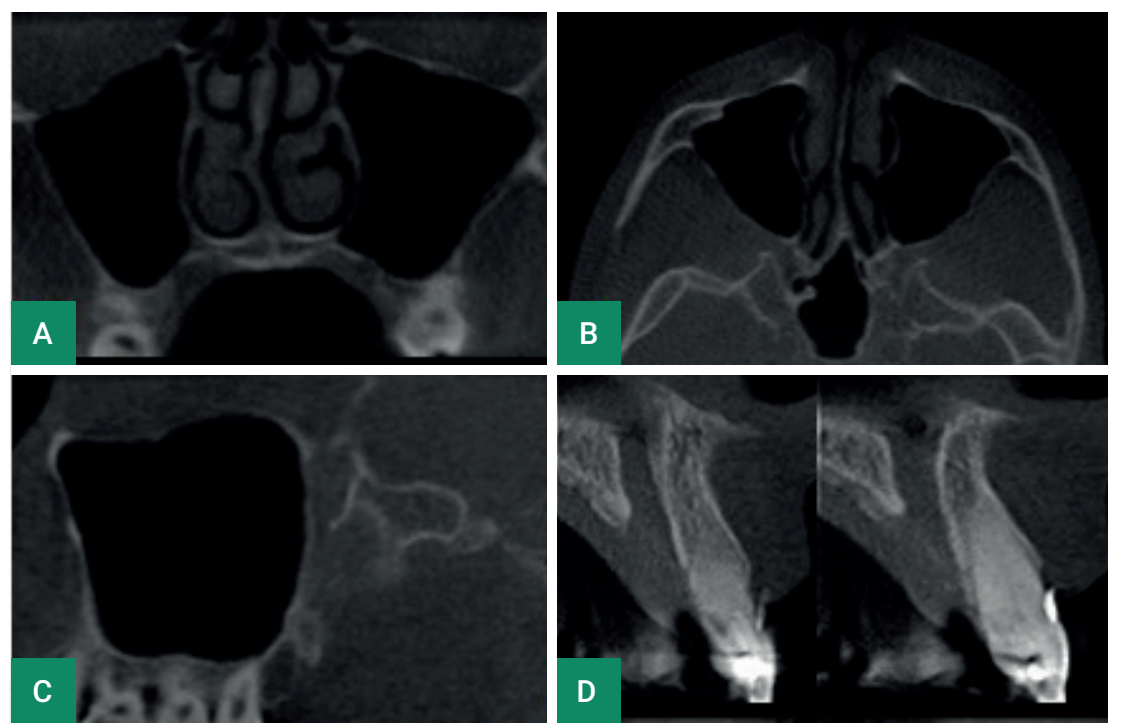

Figure 1. (A) Coronal, (B) Axial, (C) Sagital and (D) Parasagittal planes

Intraoperative imaging offers the potential to improve surgical performance in existing procedures, extend the applicability of surgery to cases that would be otherwise inoperable, and has great potential utility in training surgeons, facilitating advancing the novice surgeon from a $2 D$ to a more complete $3 D^{11,17,28,29}$. Besides that, it is especially desirable in areas that are close to vital anatomical structures, distorted anatomy, extensive sino-nasal polyposis and increased risk of intraoperative bleeding ${ }^{17}$. 


\section{Inflammatory pathology}

Periapical inflammation was shown to be capable of affecting the maxillary sinus mucosa with and without perforation of the cortical bone of the sinus floor ${ }^{30}$ (Figure 2). Untreated dental condition can cause odontogenic sinusitis that can be presented in various ways, and they are particularly characterized by inflammation and localized mucosal thickening ${ }^{23,30}$. The accurate identification of changes in the maxillary sinus with CBCT could provide the size and location of the periapical lesion, and also would help deciding if the teeth need to be treated, retreated or surgical procedure yet ${ }^{30}$.

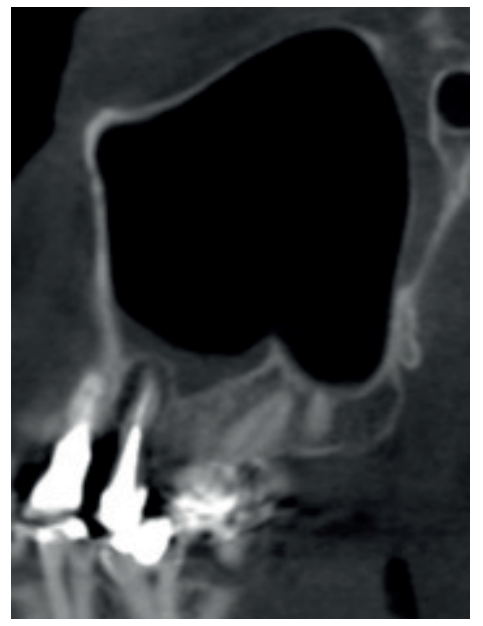

Figure 2. Periapical inflammation

Regarding the frontal sinus, some cells can block it at the level of frontal recess, causing frontal sinusitis, mainly because of inadequate removal of agger nasi and frontal recess cells during endoscopic sinus surgery ${ }^{31}$. CBCT multiplanar reconstruction could be used to identify potential causes of frontal recess stenosis and evaluates all of the cell anatomical variable with a lower use of radiating energy ${ }^{11}$.

Data gained from the CBCT scans, in addition to clinical impression and endoscopy, suggest that such images provide useful radiologic documentation for the diagnosis of chronic rhinosinusitis ${ }^{4}$, effusion, mucosal thickening and ostial obstruction are perfectly visible, with precision equal to or greater than that of MDCT. Any inflammatory or infectious sinus pathology is accessible to CBCT examination, with complete topographic exploration ${ }^{23}$.

\section{Implant placement}

For dental implant site assessment in the maxilla, the configuration and status of the maxillary sinus is important to assess the available amount of bone (Figure 3), principally if a sinus lift is indicated ${ }^{2,32}$. Incidental findings such as mucosal thickening can be associated with a sinus outflow obstruction which can impact on the clinician's treatment decisions ${ }^{26}$. Maxillary sinus septa are barriers of cortical bone that divide the maxillary sinus floor into 
multiple compartments, known as recesses ${ }^{33}$. It seems that an antral septa, detected in almost half of the CBCT exams, might increase the risk of sinus membrane perforation during the maxillary sinus floor elevation surgery ${ }^{33}$. MDCT and CBCT are definitely the preferred imaging techniques for the assessment of this anatomic variation ${ }^{32}$.

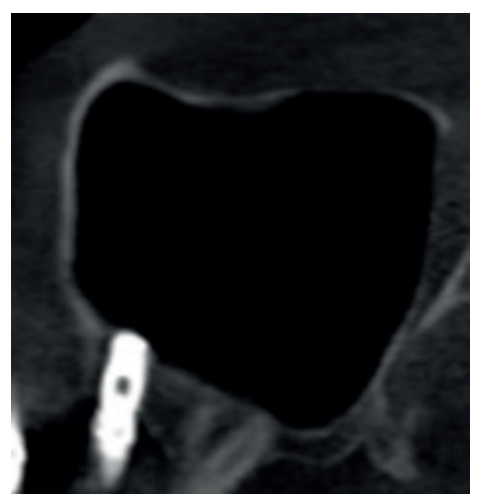

Figure 3. Relationship between dental implant and sinus floor.

\section{Anatomical variations}

The imaging investigation of anatomical variations (Figure 4) of the paranasal sinuses is important in assessing the predisposing factors for inflammatory changes of the paranasal sinuses. These changes in the sinuses are a common problem encountered in clinical practice. The most encountered variations are the concha bullosa,
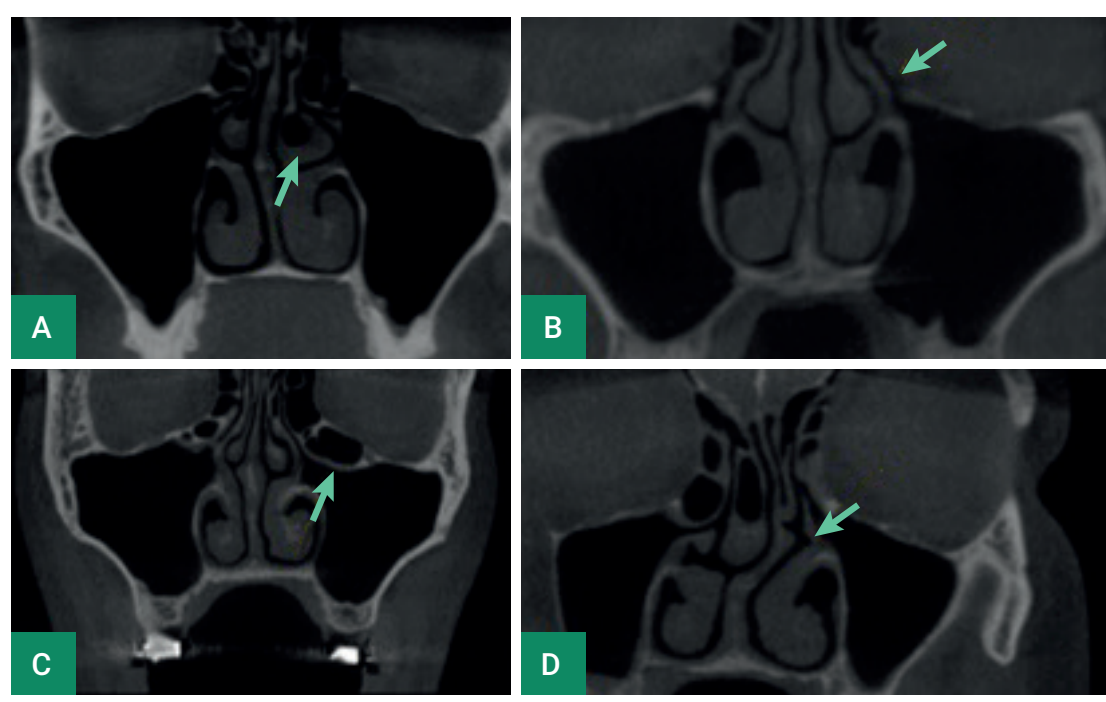

Figure 4. (A) Concha bullosa, (B) Hipertrophy of the uncinate process, (C) Haller Cell, (D) Nasal septum deviation 
Haller cell presence and the modifications of the uncinate process morphology and positions. The Haller cell is an asymptomatic maxilla ethmoidal cell and, in some situations, may narrow the osteo-meatal complex, inhibiting the ciliary function and leading to obstruction of the ostium. The uncinate process allows air flow and mucus drainage. Morphological variations of this hook-like process might be a factor of narrowing the unit and, thus, blocking the drainage and consequently producing inflammation ${ }^{13}$. Concha bullosa may be implicated as a possible etiological factor in the causation of recurrent chronic sinusitis, due to its negative influence on paranasal sinus ventilation and mucociliary clearance in the middle meatus region ${ }^{13}$.

The nasal septum deviation is also among the most observed anatomical variations ${ }^{13}$. This condition may cause compression of the nasal concha laterally, with consequent obstruction of the infundibulum, presenting clinical importance in the approach of recurrent sinusopathy ${ }^{5}$.

\section{Volumetric evaluation}

CBCT has become a widely used imaging modality for evaluating maxillary sinus volume. It is used to investigate changes before and after rapid maxillary expansion ${ }^{34}$, gender assessment ${ }^{15}$ and the effects of long-term oral breathing ${ }^{7}$. Additionally, a simulated system for medical training in upper air way related surgery can be built from the surface model. A CBCT air way segmentation scheme will provide extra information in the case of patients who have already undergone CBCT scans for other treatments such as orthodontics without the need of a high radiation dose of $\mathrm{MDCT}^{18}$. Furthermore, the frontal sinus cavity can be segmented and reconstructed for determining sex and person identification ${ }^{35}$.

\section{Final Considerations}

This review paper highlights the potential uses of CBCT in the assessment of paranasal sinuses and confirms that it is an accurate and reliable tool. Plain films offer limited information about the paranasal sinuses, with the inherent errors of a $2 \mathrm{D}$ representation of a 3D structure and the lack of information about cross-sectional area and volume. CBCT will eventually become the gold standard in routine sinus exploration, because it combines good image quality, even at low radiation exposure, short examination time, easy use and low cost in relation to MDCT and MRI. Besides, nowadays the volumetric evaluation of the paranasal sinus has been easily achieved by several open-access software. The technique's limitations, however, need to be borne in mind. It is remarkably good for bone evaluation, with excellent bone/mucosa/air contrast, but its poor density resolution is a drawback for soft-tissue contrast studies. In case of tumoral, septic or hematic soft-tissue infiltration, MDCT or MRI is mandatory. In addition, although the imaging techniques play a fundamental role in the diagnosis of sinus anatomical variations and sinus pathology, clinical examination still represent a fundamental tool for the patient's diagnostic process.

\section{Acknowledgements}

The authors would like to thank the Coordination for the improvement of Higher Education Personnel (CAPES) by financial support. The authors deny any conflicts of interest related to this study. 


\section{REFERENCES}

1. Fatterpekar GM, Delman BN, Som PM. Imaging the paranasal sinuses: Where we are and where we are going. Anat Rec (Hoboken). 2008 Nov;291(11):1564-72. doi: 10.1002/ar.20773.

2. Ritter L, Lutz J, Neugebauer J, Scheer M, Dreiseidler T, Zinser MJ, et al. Prevalence of pathologic findings in the maxillary sinus in cone beam computerized tomography. Oral Surg Oral Med Oral Pathol Oral Radiol Endod. 2011 May;111(5):634-40. doi: 10.1016/j.tripleo.2010.12.007.

3. Cagici CA, Cakmak O, Hurcan C, Tercan F. Three-slice computerized tomography for the diagnosis and follow-up of rhinosinusitis. Eur Arch Otorhinolaryngol. 2005 Sep;262(9):744-50.

4. Cakli H, Cingi C, Ay Y, Oghan F, Ozer T, Kaya E. Use of cone beam computed tomography in otolaryngologic treatments. Eur Arch Otorhinolaryngol. 2012 Mar;269(3):711-20. doi: 10.1007/s00405-011-1781-X.

5. Poorey VK, Gupta N. Endoscopic and computed tomographic evaluation of influence of nasal septal deviation on lateral wall of nose and its relation to sinus diseases. Indian J Otolaryngol Head Neck Surg. 2014 Sep;66(3):330-5. doi: 10.1007/s12070-014-0726-2.

6. Rani SU, Rao GV, Kumar DR, Sravya T, Sivaranjani Y, Kumar MP. Age and gender assessment through three-dimensional morphometric analysis of maxillary sinus using magnetic resonance imaging. J Forensic Dent Sci. 2017 Jan-Apr;9(1):46. doi: 10.4103/0975-1475.206481.

7. Agacayak KS, Gulsun B, Koparal M, Atalay Y, Aksoy O, Adiguzel O. Alterations in maxillary sinus volume among oral and nasal breathers. Med Sci Monit. 2015 Jan 2;21:18-26. doi: 10.12659/MSM.891371.

8. Liang X, Jacobs R, Hassan B, Li L, Pauwels R, Corpas L, et al. A comparative evaluation of cone beam computed tomography (CBCT) and multi-slice CT (MSCT) Part I. On subjective image quality. Eur J Radiol. 2010 Aug;75(2):265-9. doi: 10.1016/j.ejrad.2009.03.042.

9. Konen E, Faibel M, Kleinbaum Y, Wolf M, Lusky A, Hoffman C, et al. The value of the occipitomental (waters') view in diagnosis of sinusitis: A comparative study with computed tomography. Clin Radiol. 2000 Nov; $55(11): 856-60$.

10. Güldner C, Diogo I, Windfuhr J, Bien S, Teymoortash A, Werner JA, et al. Analysis of the fossa olfactoria using cone beam tomography (CBT). Acta Otolaryngol. 2011 Jan;131(1):72-8. doi: 10.3109/00016489.2010.506653.

11. Rafferty MA, Siewerdsen JH, Chan Y, Moseley DJ, Daly MJ, Jaffray DA, et al. Investigation of C-arm cone beam CT-guided surgery of the frontal recess. Laryngoscope. 2005 Dec;115(12):2138-43.

12. Shahbazian $M$, Jacobs $R$. Diagnostic value of $2 D$ and $3 D$ imaging in odontogenic maxillary sinusitis: A review of literature. J Oral Rehabil. 2012 Apr;39(4):294-300. doi: 10.1111/j.1365-2842.2011.02262.x.

13. Aramani A, Karadi RN, Kumar S. A study of anatomical variations of osteomeatal complex in chronic rhinosinusitis patients-CT findings. J Clin Diagn Res. 2014 Oct;8(10):KC01-4 doi: 10.7860/JCDR/2014/9323.4923.

14. Zojaji R, Naghibzadeh M, Mazloum Farsi Baf M, Nekooei S, Bataghva B, Noorbakhsh S. Diagnostic accuracy of cone beam computed tomography in the evaluation of chronic rhinosinusitis. ORL $J$ Otorhinolaryngol Relat Spec. 2015;77(1):55-60.

15. Saccucci M, Cipriani F, Carderi S, Di Carlo G, D’Attilio M, Rodolfino D, et al. Gender assessment through three-dimensional analysis of maxillary sinuses by means of cone beam computed tomography. Eur Rev Med Pharmacol Sci. 2015;19(2):185-93.

16. Demeslay J, Vergez S, Serrano E, Chaynes P, Cantet P, Chaput B, et al. Morphological concordance between CBCT and MDCT: a paranasal sinus-imaging anatomical study. Surg Radiol Anat. 2016 Jan;38(1):71-8. doi: 10.1007/s00276-015-1509-5.

17. Prisman E, Daly MJ, Chan H, Siewerdsen JH, Vescan A, Irish JC. Real-time tracking and virtual endoscopy in cone beam CT-guided surgery of the sinuses and skull base in a cadaver model. Int Forum Allergy Rhinol. 2011 Jan-Feb;1(1):70-7. doi: 10.1002/alr.20007. 
18. Bui NL, Ong SH, Foong KWC. Automatic segmentation of the nasal cavity and paranasal sinuses from cone beam CT images. Int J Comput Assist Radiol Surg. 2015 Aug;10(8):1269-77 doi: 10.1007/s11548-014-1134-5.

19. Scarfe WC, Farman AG. What is Cone beam CT and How Does it Work? Dent Clin North Am. 2008 Oct;52(4):707-30, v. doi: 10.1016/j.cden.2008.05.005.

20. The 2007 Recommendations of the International Commission on Radiological Protection. ICRP publication 103. Ann ICRP. 2007;37(2-4):1-332.

21. Durack C, Patel S. Cone beam computed tomography in endodontics. Braz Dent J. 2012;23(3):179-91.

22. Dahmani-Causse M, Marx M, Deguine O, Fraysse B, Lepage B, Escudé B. Morphologic examination of the temporal bone by cone beam computed tomography: Comparison with multislice helical computed tomography. Eur Ann Otorhinolaryngol Head Neck Dis. 2011 Nov;128(5):230-5. doi: 10.1016/j.anorl.2011.02.016.

23. Hodez C, Griffaton-Taillandier C, Bensimon I. Cone beam imaging: Applications in ENT. Eur Ann Otorhinolaryngol Head Neck Dis. 2011 Apr;128(2):65-78. doi: 10.1016/j.anorl.2010.10.008.

24. Al Abduwani J, Zilinskiene L, Colley S, Ahmed S. Cone beam CT paranasal sinuses versus standard multidetector and low dose multidetector CT studies. Am J Otolaryngol. 2016 Jan-Feb;37(1):59-64. doi: 10.1016/j.amjoto.2015.08.002.

25. Bremke M, Sesterhenn AM, Murthum T, Al Hail A, Bien S, Werner JA. Digital volume tomography (DVT) as a diagnostic modality of the anterior skull base. Acta Otolaryngol. 2009 Oct;129(10):1106-14. doi: $10.1080 / 00016480802620621$.

26. Rege IC, Sousa T, Leles C, Mendonça E. Occurrence of maxillary sinus abnormalities detected by cone beam CT in asymptomatic patients. BMC Oral Health. 2012 Aug 10;12:30. doi: 10.1186/1472-6831-12-30.

27. Queiroz PM, Oliveira ML, Groppo FC, Haiter-Neto F, Freitas DQ. Evaluation of metal artefact reduction in cone beam computed tomography images of different dental materials. Clin Oral Investig. 2018 Jan;22(1):419-423. doi: 10.1007/s00784-017-2128-9.

28. Daly MJ, Siewerdsen JH, Moseley DJ, Jaffray DA, Irish JC. Intraoperative cone beam CT for guidance of head and neck surgery: Assessment of dose and image quality using a C-arm prototype. Med Phys. 2006 Oct;33(10):3767-80

29. Göçmez C, Göya C, Hamidi C, Teke M, Hattapoğlu S, Kamaşak K. Evaluation of the surgical anatomy of sphenoid ostium with 3D computed tomography. Surg Radiol Anat. 2014 Oct;36(8):783-8. doi: 10.1007/s00276-013-1245-7.

30. Maillet M, Bowles WR, McClanahan SL, John MT, Ahmad M. Cone beam computed tomography evaluation of maxillary sinusitis. J Endod. 2011 Jun;37(6):753-7. doi: 10.1016/j.joen.2011.02.032.

31. Minni A, Messineo D, Attanasio G, Pianura E, D’Ambrosio F. 3D cone beam(CBCT) in evaluation of frontal recess: Findings in youth population. Eur Rev Med Pharmacol Sci. 2012 Jul;16(7):912-8.

32. Shahidi S, Zamiri B, Momeni Danaei S, Salehi S, Hamedani S. Evaluation of Anatomic Variations in Maxillary Sinus with the Aid of Cone Beam Computed Tomography (CBCT) in a Population in South of Iran. J Dent (Shiraz). 2016 Mar;17(1):7-15.

33. Orhan K, Kusakci Seker B, Aksoy S, Bayindir H, Berberoğlu A, Seker E. Cone beam CT evaluation of maxillary sinus septa prevalence, height, location and morphology in children and an adult population. Med Princ Pract. 2013;22(1):47-53. doi: 10.1159/000339849.

34. Oz AZ, Oz AA, El H, Palomo JM. Maxillary sinus volume in patients with impacted canines. Angle Orthod. 2017 Jan;87(1):25-32. doi: 10.2319/122915-895.1.

35. Choi IGG, Duailibi-Neto EF, Beaini TL, da Silva RLB, Chilvarquer I. The Frontal Sinus Cavity Exhibits Sexual Dimorphism in 3D Cone beam CT Images and can be Used for Sex Determination. J Forensic Sci. 2018 May;63(3):692-698. doi: 10.1111/1556-4029.13601. 